\title{
Karakter Siswa Kelas IV Sekolah Dasar di Kota Cirebon
}

\author{
Jairoh Rakmawati ${ }^{1}$, DPD Santi ${ }^{2}$, dan Khomarruzaman ${ }^{3}$ \\ Progam Studi Pendidikan Guru Sekolah Dasar, FKIP, Universitas Swadaya Gunung Jati; \\ jairohrakmawati@gmail.com ${ }^{1}$, dinapratiwids@fkip-unswagati.ac.id² ${ }^{2}$, \\ zamanenyghazy@gmail.com $^{3}$
}

\begin{abstract}
Abstrak. Dalam kegiatan penelitian, peneliti menemukan permasalahan yang terjadi dalam kegiatan pembelajaran di kelas salah satunya, yaitu tentang karakter siswa disiplin, bertanggung jawab dan percaya diri masih rendah sehingga masih banyak siswa yang kurang baik dalam menerapkan karakter tersebut dalam kegiatan pembelajaran. Penelitian ini bertujuan untuk mengetahui karakter yang ada di sekolah tersebut untuk diimplementasikan dalam lingkungan sekolah ataupun di lingkungan sehari-hari yang digunakan sebagai tempat sosialisasi siswa, yang mengacu pada pembelajaran kurikulum 2013 yang mewajibkan pendidikan karakter selama kegiatan belajar mengajar. Penelitian ini adalah penelitian kualitatif dan jenis penelitian deskriptif, teknik pengumpulan data yang digunakan angket terbuka menggunakan skala Guttman. Hasil penelitian menunjukan bahwa sebagian besar siswa kelas IV di SDN Karang Jalak 1 Kota Cirebon sudah berkarakter dengan baik.
\end{abstract}

Kata Kunci: Karakter disiplin, tanggung jawab dan percaya diri.

\begin{abstract}
In research activities, researchers found problems that occur in learning activities in class, one of which, namely about the character of students' discipline, responsibility and selfconfidence is still low so that there are still many students who are not good at applying these characters in learning activities. This study aims to determine the characters in the school to be implemented in the school environment or in the everyday environment used as a place for student socialization, which refers to the 2013 curriculum learning which requires character education during teaching and learning activities. This research is a qualitative research and descriptive research type, the data collection technique used is an open questionnaire using the Guttman scale. The results showed that most of the fourth grade students at SDN Karang Jalak 1 Cirebon City had good character.
\end{abstract}

Keywords: Discipline character, responsibility and self-confidence.

\section{Pendahuluan}

Pendidikan karakter menjadi modal utama dalam kurikulum 2013 yang harus diimplementasikan ke dalam lembaga pendidikan formal di seluruh jenjang pendidikan. Penerapan pendidikan karater ini merupakan salah satu cara dalam mencapai tujuan pendidikan nasional yaitu menjadikan siswa manusia yang beriman dan bertakwa kepada tuhan yang maha esa, berakhlak mulia, sehat, berilmu, cakap, kreatif, mandiri dan menjadikan warga negara yang demokratis serta bertanggung jawab. Menurut Simon (Asyiah \& Sunanto, 2014) karakter adalah kumpulan tata nilai yang tertuju pada suatu sistem yang melandasi pemikiran, sikap dan perilaku yang ditampilkan. Sedangkan Lickona (2015) mengemukakan karakter dikonsepsikan memiliki tiga bidang yakni moral knowing, moral feeling dan moral action. Oleh karena itu, karakter 
yang baik memiliki tiga kompetensi menjadi kebiasaan berfikir, kebiasaan hati dan kebiasaan bertindak. Khusnianti (Ramli, 2014) menyatakan pendidikan karakter memiliki esensi dan makna yang sama dengan pendidikan akhlak, tujuannya adalah membentuk pribadi anak supaya menjadi manusia yang baik, warga masyarakat dan warga negara yang baik. Jadi pendidikan karakter adalah pendidikan yang mengacu pada kemampuan sehari-hari anak yang dilakukan secara spontan dari hati, jiwa dan bawaan, kepribadian, perilaku dan budi pekerti yang dimiliki seseorang.

Berdasarkan hasil pengamatan di SD Negeri Karang Jalak 1 Kota Cirebon pada kelas IV SD pembelajarannya sudah memunculkan pendidikan karakter yang dicirikan sebagai pendidikan yang berdasarkan kurikulum 2013. Guru memunculkan pendidikan karakter pada proses kegiatan inti belajar yang dilakukan oleh siswa untuk meningkatkan mutu pendidikan moral, sehingga siswa dapat memahami karakter siswa yang lainnya. Dalam pembelajaran ini, siswa mengeluarkan karakternya seperti tanggung jawab, percaya diri dan disiplin yang dilakukan pada proses belajar di dalam kelas maupun di luar kelas. Dengan begitu tujuan pembelajaran yang sudah ditetapkan dapat terlaksana dengan baik. Hal ini didukung oleh tujuan pendidikan adalah segala sesuatu yang dilakukan guru, yang mampu mempengaruhi karakter siswa, guru membantu membentuk watak siswa berdasarkan prinsip-prinsip pendidikan karakter (Bahri, S., 2015: 7). Yang mana bahwa pendidikan karakter membuat siswa dapat memuculkan sikap yang spontan sehingga siswa tidak merasa beban dalam mealukannya.

Proses di dalam suatu pembelajaran agar berhasil dan dapat mecapai tujuan yang diinginkan oleh gurunya yaitu guru harus memberikan dorogan atau penguatan dalam proses belajar mengajar secara langsung, memfasilitasi, memberikan siswa peluang untuk dapat belajar secara aktif dan kreatif, untuk mengembangkan bakat, minat dan sikap melalui kegiatan belajar yang terencana. Sebagai usaha menanamkan karakter siswa kelas IV guru perlu menerapkan pendidikan karakter di kegiatan belajar mengajar secara langsung dan siswa dapat mengimplementasikannya pada kehidupan seharihari. Jadi pendidikan karakter yang digunakan oleh guru sangat penting dalam peningkatan karakter siswa. Dengan demikian, pendidikan karakter akan bermanfaat bagi siswa karena dapat memberikan kemampuan berinteraksi atau komunikasi dengan teman sebayanya untuk bertanggung jawab, percaya diri dan mandiri dalam melakukan sesuatu. 
Penelitian terkait menjadi salah satu acuan bagi penulis untuk memperkuat teori yang akan digunakan dalam mengkaji penelitian, penulis mengangkat beberapa penelitian untuk referensi dalam menulis sebuah laporan penelitian yang dilakukan oleh penulis. Berikut merupakan penelitian terdahulu yang dilakukan oleh orang lain berbentuk jurnal terkait dengan penelitian yang dilakukan oleh penulis sebagai bahan bacaan.

Penelitian yang dilakukan oleh Alfian (2014) dengan judul penerapan pendidikan karakter nilai disiplin dan nilai tanggung jawab dalam mata pelajaran pendidikan jasmani, olahraga, dan kesehatan (PJOK) di kelas I dan IV SD Negeri percobaan 3. Tujuan dalam penelitian ini untuk mendeskripsikan penerapan pendidikan karakter dalam mata pelajaran PJOK kelas I dan IV di SD Negeri percobaan 3 yang berkaitan dengan nilai disiplin dan nilai tanggung jawab. Pendekatan yang digunakan dalam penelitian ini adalah penelitian kualitatif dengan jenis penelitian yaitu deskriptif, sedangkan cara mengumpulkan data dalam penelitian ini dengan cara observasi dan wawancara untuk mengetahui data faktual. Hasil dari penelitian ini yaitu penerapan pendidikan karakter di SD Negeri Percobaan 3 dalam pelajaran PJOK yang khususnya di kelas I Dan IV.

Penelitian yang dilakukan oleh Pangestika (2018) dengan judul hubungan rasa percaya diri dengan motivasi berprestasi pada mata pelajaran IPA. Tujuan dalam penelitian ini untuk mengetahui seberapa besar hubungan rasa percaya diri dengan motivasi berprestasi pada mata pelajaran IPA siswa kelas V sekolah dasar se-gugus 5 Kecamatan pengasih Kabupaten Kulon Progo. Penelitian ini menggunakan pendekatan kualitatif dengan metode Ex Post Facto, sedangkan pengumpulan data menggunakan instrumen kuesioner yang berupa skala psikologi. Hasil dari penelitian ini yaitu terdapat hubungan positif dan signifikan antara rasa percaya diri dengan motivasi berprestasi, dengan nilai korelasi 0,716. Besarnya angka korelasi tersebut menunjukan bahwa tingkat hubungan antara variabel rasa percaya diri dengan motivasi berprestasi IPA termasuk dalam kategori tinggi.

Penelitian yang dilakukan oleh Mulyaningsih (2015) dengan judul implementasi pendidikan karakter pada pembelajaran tematik di kelas IV SD Negeri prembulan galur kulon progo. Tujuan dalam penelitian ini untuk mendeskripsikan nilai-nilai karakter, implementasi pendidikan karakter, dan hambatan dalam mengimplementasikan pendidikan karakter pada pembelajaran tematik di kelas IV SD Prembulan. Penelitian ini menggunakan pendekatan kualitatif dengan jenis deskriptif, sedangkan pengumpulan data 
menggunakan observasi, wawancara dan dokumentasi. Hasil dari penelitian ini yaitu implementasi pendidikan karakter terdiri atas perencanaan dan pelaksanaan yang dilakukan oleh guru.

Dari hasil ketiga penelitian diatas terdapat penelitian yang memiliki keterkaitan dengan penelitian ini yaitu penelitian dari Alfian Budi dengan Irma Mulyaningsih yang bertujuan untuk mendeskripsikan nilai-nilai karakter dan mengimplementasikan nilai-nilai karakter pada pembelajaran yang dilakukan mengacu pada kurikulum 2013 yang sedang berlaku pada jenjang pendidikan.

\section{Metode}

Dalam penelitian ini menggunakan pendekatan kualitatif dan jenis penelitian yang bersifat deskriptif. Penulis menggunakan penelitian ini karena untuk mengetahui secara jelas dan fakta dalam karakter disiplin, tanggung jawab dan percaya diri selama pembelajaran yang dilakukan di SD Negeri Karang Jalak 1 Kota Cirebon Kelas IV. Pengumpulan data dengan teknik observasi dan dokumentasi, pengumpulan data dan informasi dilakukan secara langsung dalam proses pembelajaran yang sedang dilakukan oleh penulis.

Menurut Husna (2015: 77) populasi adalah kelompok subjek yang hendak dikenai generalisasi hasil penelitian. Sebagai suatu populasi, kelompok subjek ini harus memiliki ciri-ciri atau karakteristik bersama yang membedakan dari kelompok subjek yang lain. Oleh karena itu dalam penelitian ini yang digunakan populasi yaitu seluruh siswa di SD Negeri Karang Jalak 1 Kota Cirebon. Sedangkan pengambilan sampel merupakan suatu proses pemilihan dan penentuan jenis sampel dan perhitungan besarnya sample yang akan menjadi subjek atau objek penelitian (Husna 2015: 77). untuk metode pengambilan sampel akan digunakan non probability sampling yaitu teknik pengambilan sampel berdasarkan penilaian personal individu. Oleh karena itu dalam penelitian ini sampel yang digunakan seluruh siswa kelas IV di SD Negeri Karang Jalak 1 Kota Cirebon.

Proses pengumpulan data pada penelitian ini menggunakan observasi dan angket (kuesioner) untuk mendapatkan data secara faktual dalam proses pembelajaran yang dilakukan. Teknik pengumpulan data observasi menurut Nana (2017 : 220). Suatu teknik atau cara mengumpulkan data dengan jalan mengadakan pengatan terhadap kegiatan yang sedang berlangsung. Kegiatan ini bisa berkenaan dengan kegiatan guru mengajar, siswa belajar, kepala sekolah yang sedang memberikan pengarahan belajar. Oleh karena itu 
observasi yang dilakukan dalam penelitian ini secara langsung dalam proses pembelajaran secara pengamatan karakter di kegiatan inti belajar. Sedangkan instrumen yang digunakan dalam penelitian ini yaitu angket (kuesioner) digunakan untuk mengetahui karakter siswa dalam proses belajar di kelas, karakter yang ingin diketahui yaitu karakter tanggung jawab, karakter disiplin dan karakter percaya diri. Menurut Sugiyono (dalam Edy \& Mudjia 2014:137) angket (kuesioner) merupakan teknik pengumpulan data yang dilakukan dengan cara memberi pretayaan atau pertanyaan tertulis kepada responden untuk dijawab.

Teknik pengolahan data menggunakan angket (kuesioner) yang di dalamnya terdapat seperangkat daftar pertanyaan yang telah disusun sebelumnya. Pengumpulan data dilakukan dengan menggunakan skala Guttman. Angket yang digunakan dalam penelitian ini yaitu angket terbuka yang jawabanya Ya atau Tidak.

Tabel 1. Skoring Kuesioner Karakter Siswa

\begin{tabular}{ccc}
\hline Alternatif Jawaban & Skor Positif & Skor Negatif \\
\hline Ya & 1 & 0 \\
Tidak & 0 & 1 \\
\hline
\end{tabular}

Jawaban dari responden yang tertinggi diberi nilai "satu" dan terendah akan diberi nilai "nol". Jika pernyataan positif maka jawaban Ya $=1$ dan Tidak $=0$. Sedangkan, jika pernyataan negatif maka jawaban $\mathrm{Ya}=0$ dan Tidak $=1$. Penelitian ini juga menggunakan kisi-kisi sebagai dasar pembuatan kuesioner. Adapun kisi-kisi yang dimaksud akan disajikan ke dalam tabel 2.

Tabel 2. Kisi-Kisi Kuesioner Karakter Siswa

\begin{tabular}{|c|c|c|}
\hline \multicolumn{2}{|c|}{$\begin{array}{l}\text { No } \\
\text { Disiplin }\end{array}$} & Pernyataan \\
\hline 1 & $\begin{array}{l}\text { Ketaatan terhadap tata tertib } \\
\text { sekolah. }\end{array}$ & $\begin{array}{l}\text { 1) Saya masuk kelas tepat } \\
\text { waktu. } \\
\text { 2) Saya memakai seragam } \\
\text { sesuai dengan tata tertib } \\
\text { sekolah. }\end{array}$ \\
\hline 2 & $\begin{array}{l}\text { Ketaatan dalam mengerjakan } \\
\text { tugas-tugas pelajaran. }\end{array}$ & $\begin{array}{l}\text { 3) Saya mengumpulkan tugas } \\
\text { tepat waktu. } \\
\text { 4) Saya mengerjakan tugas yang } \\
\text { diberikan guru. }\end{array}$ \\
\hline & & $\begin{array}{l}\text { 5) Saya mengikuti praktikum } \\
\text { sesuai dengan langkah- }\end{array}$ \\
\hline
\end{tabular}


3 Disiplin terhadap kegiatan belajar di sekolah. langkah yang disiapkan oleh guru.

6) Saya tertib dalam mengikuti pembelajaran dikelas.

7) Saya tidak bergurau jika sedang mengikuti pembelajaran.

8) Saya membawa buku pelajaran sesuai dengan mata pelajaran.

Tanggung Jawab

1 Melaksanakan tugas individu dengan baik.

2 Menerima resiko dan tindakan yang dilakukan.

3 Mengembalikan barang yang dipinjam.

4 Mengakui dan meminta maaf atas kesalahan yang dilakukan.
1) Saya mengerjkan piket sesuai dengan jadwal yang ada dikelas.

2) Saya melakukan tugas yang diberikan guru dengan baik.

3) Saya siap menjadi petugas upacara jika sesuai dengan jadwal kegiatan.

4) Sebelum belajar saya merapihkan tempat duduk dengan baik.

5) Setelah belajar saya merapihkan tempat duduk dengan baik.

6) Saya siap menerima hukuman jika tidak melakukan piket.

7) Saya berani mengembalikan penghapus yang telah dipinjem.

8) Saya berani meminta maaf jika telah melakukan keselahan yang merugikan orang lain.

\begin{tabular}{lll}
\hline \multicolumn{2}{c}{ Percaya Diri } & \\
\hline 1 & $\begin{array}{l}\text { Memiliki kemampuan hebat } \\
\text { pada diri sendiri. }\end{array}$ & 1) $\begin{array}{l}\text { Saya berani presentasi di } \\
\text { depan kelas. }\end{array}$ \\
2 & Berani. & 2) $\begin{array}{l}\text { Saya berani berpendapat } \\
\text { tanpa ragu-ragu. }\end{array}$ \\
\hline
\end{tabular}


3 Gigih dan tekun.

4 Bersemangat.
3) Saya berani menyimpulkan pembelajaran dengan benar.

4) Saya berani bertanya jika materi yang dijelaskan kurang dimengerti.

5) Saya berani melakukan keputusan dengan cepat.

6) Saya tidak mencontek jika sedang mengerjakan soal.

7) Saya tidak putus asa jika PR yang dikerjakan masih kurang tepat jawabanya.

8) Saya berani menjawab pertanyaan yang diberikan oleh guru dengan cepat.

Data-data yang berisi jawaban dari siswa merupakan data-data yang masih mentah, kemudian data tersebut diolah atau dianalisis secara sistematis. Adapun menurut Prasetyo \& Jannah (dalam Munggaran, 2012) salah satu langkah dalam pengolahan data, yakni penganalisan data (data analyzing) adalah data suatu proses lanjutan dari proses pengolahan data untuk melihat bagaimana menginterprestasikan data, kemudian menganalisis data dari hasil yang sudah ada pada tahap hasil pengolahan data (Prasetyo \& Jannah, 2010: 171). Dari data yang diperoleh merupakan data kuantitatif dengan menggunakan skala Guttman. Adapun teknik statistik yang digunakan dalam penelitian ini adalah presentase. Adapun rumusnya sebagai berikut (Bungin, 2010: 177).

$$
P=\frac{f}{n} \times 100 \%
$$

Keterangan:

$P \quad=$ Prosentase

$f \quad=$ Frekuensi dari setiap jawaban yang dipilih

$n \quad=$ Jumlah siswa

Selanjutnya, persentase yang diperoleh diterjemahkan ke dalam kategori sebagai berikut:

Tabel 3. Kategori Presentase

\begin{tabular}{cc}
\hline Persentase & Kategori \\
\hline $0-1 \%$ & Tidak ada \\
$2 \%-25 \%$ & Sebagian kecil \\
$26 \%-49 \%$ & Kurang dari setengahnya \\
\hline
\end{tabular}




\begin{tabular}{cc}
\hline Persentase & Kategori \\
\hline $50 \%$ & Setengahnya \\
$51 \%-75 \%$ & Lebih dari setengahnya \\
$76 \%-99 \%$ & Sebagian besar \\
$100 \%$ & Seluruhnya \\
\hline
\end{tabular}

\section{Hasil dan Pembahasan}

Berdasarkan hasil pengisian kuesioner yang dilakukan oleh siswa kelas IV di SDN Karang Jalak 1 akan dipaparkan melalui Tabel 4, Tabel 5 dan Tabel 6.

Tabel 4. Hasil Skor Pengisian Kuesioner Disiplin Siswa Kelas IV di SDN

\begin{tabular}{cc}
\multicolumn{3}{c}{ Karang Jalak 1} \\
\hline Pernyataan Disiplin & Skor Jawaban Ya (\%) \\
\hline 1 & 100 \\
2 & 81,25 \\
3 & 100 \\
4 & 100 \\
5 & 93,75 \\
6 & 100 \\
7 & 100 \\
8 & 100 \\
Total & 775 \\
Rata-rata & 96,875 \\
\hline
\end{tabular}

Berdasarkan tabel di atas dapat disimpulkan bahwa rata-rata karakter disiplin sebesar 96,875 menunjukan sebagian besar sudah disiplin. Pernyataan nomor 2 dan 5 meskipun tidak menghasilkan nilai 100 tetapi sudah menunjukan nilai baik dengan rentang nilai $76 \%$ - $99 \%$ pada siswa kelas IV SDN Karang Jalak 1 Kota Cirebon sehingga siswa dapat menerapkan aspek disiplin dengan baik dan benar. Artinya masih terdapat beberapa siswa yang kurang disiplin, faktor yang menyebabkan hal tersebut adalah siswa kurang menaati aturan yang ada di sekolah dan kurang kesadaran diri dalam menerapkan sikap tersebut. Jika dibiarkan maka kondisi pembelajaran kurang berjalan dengan baik dan akan mengahambat pada tujuan pembelajaran yang akan dicapai.

Menurut Salahudin (2015: 111) upaya meningkatkan karakter disiplin merupakan tindakan yang menunjukan perilaku tata tertib dan patuh pada berbagai ketentuan dan peraturan yang ada disekolah. Sedangkan menurut Samani (2015 : 121) upaya meningkatkan karakter disiplin yaitu sikap dan perilaku yang muncul sebagai akibat dari pelatihan atau kebiasaan menaati aturan, hukuman atau perintah. Sehingga dapat disimpulkan bahwa 
karakkter disiplin adalah sikap dan perbuatan seseorang untuk menaati atau menerapkan aturan yang ada di sekolah.

Tabel 5. Hasil Skor Pengisian Kuesioner Tanggung Jawab Siswa Kelas IV di SDN Karang Jalak 1

\begin{tabular}{cc}
\hline Pernyataan Disiplin & Skor Jawaban Ya (\%) \\
\hline 1 & 100 \\
2 & 93,75 \\
3 & 100 \\
4 & 100 \\
5 & 100 \\
6 & 93,75 \\
7 & 100 \\
8 & 100 \\
Total & 787,5 \\
Rata-rata & 98,4375 \\
\hline
\end{tabular}

Berdasarkan tabel di atas dapat disimpulkan bahwa rata-rata karakter tanggung jawab sebesar 98,4375 menunjukan sebagian besar sudah bertanggung jawab. Pernyataan nomor 2 dan 6 meskipun tidak menghasilkan nilai 100 tetapi sudah mendaptkan nilai 93,75 menunjukan nilai baik dengan rentang nilai $76 \%$ - $99 \%$ pada siswa kelas 4 SDN Karang Jalak 1 Kota Cirebon sehingga siswa dapat menerapkan aspek bertanggung jawab dengan baik dan benar. Dangen kata lain, masih terdapat beberapa siswa yang kurang bertanggung jawab. Faktor yang menyebabkan hal tersebut adalah siswa kurang kesadaran dalam mempunyai tugas yang ada disekolah, sehingga siswa sering mendapat hukuman dari gurunya untuk bertanggung jawab atas kesalahan yang telah dilakukan siswa. Jika dibiarkan maka kondisi belajar kurang berjalan dengan baik akan mengahambat pada tujuan pembelajaran yang akan dicapai.

Menurut Samani (2015: 121) upaya meningkatkan karakter tanggung jawab merupakan sikap dan perilaku yang muncul sebagai akibat dari pelatihan atau kebiasaan menaati aturan, hukuman atau perintah. Sedangkan menurut Salahudin (2015: 111) upaya meningkatkan karakter tanggung jawab adalah tindakan yang menunjukan perilaku tertib dan patuh pada berbagai ketentuan dan perturan yang ada disekolah, sehingga dapat menyelesaikan tugasnya dengan baik. Sehingga dapat disimpulkan bahwa karakter tanggung jawab adalah perilaku seseorang yang harus diselesaikan dengan waktu yang disediakan untuk menyelesaikan tugasnya dengan tepat. 
Tabel 6. Hasil Skor Pengisian Kuesioner Percaya Diri Siswa Kelas IV di SDN Karang Jalak 1

\begin{tabular}{cc}
\hline Pernyataan Disiplin & Skor Jawaban Ya $(\%)$ \\
\hline 1 & 93,75 \\
2 & 75 \\
3 & 100 \\
4 & 93,75 \\
5 & 100 \\
6 & 100 \\
7 & 100 \\
8 & 100 \\
Total & 762,5 \\
Rata-rata & 95,3125 \\
\hline
\end{tabular}

Berdasarkan tabel di atas dapat disimpulkan bahwa rata-rata karakter percaya diri sebesar 95,3125 menunjukan sebagian besar sudah percaya diri. Pernyataan nomor 1 dan 4 meskipun tidak menghasilkan nilai 100 tetapi sudah mendapatkan nilai 93,75 menunjukan nilai baik dengan rentang nilai 76\%-99\% pada siswa kelas IV SDN Karang Jalak 1 Kota Cirebon sehingga siswa dapat menerapkan aspek percaya diri dengan baik dan benar. Dan masih terdapat beberapa siswa yang kurang percaya diri dengan diri sendiri, faktor yang menyebabkan hal tersebut adalah siswa kurang bersosialisai dan masi mendengarkan hasil kerja orang lain dalam proses pembelajaran. Jika dibiarkan maka kondisi pembelajaran kurang berjalan dengan baik akan mengahambat pada tujuan pembelajaran yang akan dicapai.

Menurut Agustin (2015: 22) upaya meningkatkan karakter percaya diri merupakan individu yang percaya dirinya mampu untuk melakukan sesuatu, maka akan timbul rasa percaya diri untuk menyelesaikan tugas yang ada di sekolah. Sedangkan menurut Pangestika (dalam Salirawati, 2018 : 219) upaya meningkatkan karakter percaya diri menyebutkan bahwa siswa yang memiliki rasa percaya diri rendah akan dihantui dengan perasaan takut gagal, mudah putus asa, merasa diri tidak mampu dan selalu bimbang dalam memutuskan persoalan. Sehingga dapat disimpulkan bahwa karakter percaya diri adalah untuk melalukan sesuatu yang memiliki rasa percaya diri untuk menyelesaikan suatu pekerjan dengan tidak mudah putus asa dengan kemampuan yang dimilikinya.

\section{Simpulan}


Berdasarkan hasil penelitian di atas dapat disimpulkan bahwa sebagian besar siswa kelas IV SDN Karang Jalak 1 Kota Cirebon mempunyai karakter seperti disiplin, tanggung jawab dan percaya diri. Hal ini dapat dilihat dari semua indikator angket siswa sudah mencapai baik dan dikategorikan sebagian besar baik dengan rentang nilai 76\%-99\%. Indikator yang dimaksud adalah melaksanakan tugas individu dengan baik, menyelesaikan tugas dengan waktu yang ditentukan atau disuruh untuk mengerjakannya, menghindarkan kecurangan dalam mengerjakan tugas, melakukan pekerjaan sebaik mungkin untuk mendapatkan hasil yang maksimal.

\section{Daftar Pustaka}

Agustin, M. (2011). Permasalahan belajar dan inovasi pembelajaran. Bandung: Refika Aditama.

Alfian, B. (2014). Penerapan Pendidikan Karakter Nilai Disiplin Dan Nilai Tanggung Jawab Dalam Mata Pelajaran Pendidikan Jasmani, Olahraga, Dan Kesehatan (PJOK) Di Kelas I Dan IV SD Negeri Percobaan 3. Jurnal pendidikan karakter, 4 (07), 08.

Asyiah, N., \& Sunanto, L. (2014, December). Optimalisasi Penerapan Pendidikan Karakter Pada "Kurikulum 2013" Menggunakan Strategi 3m Di Sekolah Dasar. In Prosiding Seminar Nasional Pendidikan Dasar Membedah Anatomi Kurikulum 2013 untuk Membangun Masa Depan Pendidikan yang Lebih Baik (p. 156). UPI Sumedang Press.

Bahri, S. (2015). Implementasi Pendidikan Karakter dalam Mengatasi Krisis Moral di Sekolah. Ta'allum: Jurnal Pendidikan Islam, 3(1), 57-76.

Husna, S. F., Mukhtar, E., \& Mahmud, C. (2015). Dinamika Populasi dan Sampel Anakan Pohon Klimaks Calophyllum soulattri Burm dan Swintonia schwenkii T. \&B Di Hutan Bukit Pinang-Pinang. Jurnal Biologi Universitas Andalas, 77.

Khusniati, M. (2014). Pendidikan Karakter Melalui Pembelajaran IPA. Jurnal Pendidikan IPA Indonesia, 1(2).

Lickona. (2015). Implementasi pendidikan karakter dalam pembentukan kepribadian holistik siswa. Jurnal Pendidikan Karakter, (1).

Mulyaningsih, I. (2015). Implementasi Pendidikan Karakter pada Pembelajaran Tematik di Kelas IV SD Negeri Prembulan Galur Kulon Progo. BASIC EDUCATION, 4(11).

Nana. (2017). Perbedaan Kemampuan Berpikir Kritis Siswa Melalui Penerapan Model Inkuiri Terbimbing di Sekolah Dasar. Jurnal Pendidikan Sekolah Dasar (JPsd), 3(2), 215-227. 
Pangestika, S. (2018). Hubungan Rasa Percaya Diri dengan Motivasi Berprestasi Pada Mata Pelajaran IPA. BASIC EDUCATION, 7(10), 965974.

Prasetyo, B., \& Jannah, L. M. (2010). Metode Penelitian Kuantitatif: teori dan aplikasi. RajaGrafindo Persada.

Salahudin. (2015). Pendidikan Karakter Tanggung Jawab dan Disiplin pada Anak di Keluarga Single Parent (Studi Kasus di Desa Bowan Rt. 03/05 Kabupaten Sukoharjo) (Doctoral dissertation, Universitas Muhammadiyah Surakarta).

Samani. (2015). Implementasi Pembentukan Karakter Disiplin dan Tanggung Jawab Mahassiswa Aktivis HMPS Pendidikan Guru Sekolah Dasar di Universitas Muhamadiyah Purwoketo (Doctoral dissertation, UNIVERSITAS MUHAMMADIYAH PURWOKERTO).

Sugiyono. (2014). Metode penelitian kualitatif. Jakarta : PT Raja grafindo persada. 